\title{
Retraction note to: Prevalence of the C282Y and H63D mutations of the HFE hemochromatosis gene in Azerian major $\beta$-thalassemia and iron overload
}

\author{
Abolhassan Ghaderi ${ }^{1}$ - Mohammad Reza Hafezi Ahmadi ${ }^{2}$ Ehsan Hosseini ${ }^{3}$. $^{2}$ \\ Ali Akbar Movasaghpour Akbari ${ }^{1}$ Abbas Ali Hosein Pour Feyzi ${ }^{4}$ Ataollah Hiradfar ${ }^{5}$. \\ Majid Farshdousti Hagh ${ }^{4}$
}

Published online: 4 November 2016

(C) Springer-Verlag London 2016

\section{Retraction note to: Comparative Clinical Pathology 25(1):151-154 \\ DOI: 10.1007/s00580-015-2156-2}

This article has been retracted at the request of the Editorin-Chief per the Committee on Publication Ethics guidelines. The article shows evidence of irregularities in authorship during the submission process, there is strong reason to believe that the peer review process was compromised and the article contains patchwork plagiarism from a variety of sources.

The main sources are:

Hong Kong Med J 2000;6:153-8 | Number 2, June 2000

The online version of the original article can be found at http://dx.doi. org/10.1007/s00580-015-2156-2.

Majid Farshdousti Hagh

m.farshdousti@gmail.com

1 Department of Hematology, Faculty of Medicine, Tabriz University of Medical Sciences, Tabriz, Iran

2 Department of Pathology, Ilam University of Medical sciences, Ilam, Iran

3 Department of Physiology, Faculty of Para-Veterinary Medicine, Ilam University, Ilam, Iran

4 Hematology and Oncology Research Center, Tabriz University of Medical Sciences, Tabriz, Iran

5 Children Hospital Research Center, Tabriz University of Medical Sciences, Tabriz, Iran
The $\mathrm{C} 282 \mathrm{Y}$ mutation of the HFE gene is not found in Chinese haemochromatotic patients: multicentre retrospective study

WMS Tsui, PWY Lam, KC Lee, KF Ma, YK Chan, MWY Wong, SP Yip, CSC Wong, ASF Chow, STH Lo

European Journal of Immunogenetics

Volume 27, Issue 3, pages 129-134, June 2000

Iron-overload and genotypic expression of HFE mutations $\mathrm{H} 63 \mathrm{D} / \mathrm{C} 282 \mathrm{Y}$ and transferrin receptor Hin6I and BanI polymorphism in German patients with hereditary haemochromatosis

R. Gottschalk, C. Seidl, S. Schilling, A. Braner, E. Seifried, D. Hoelzer and J. P. Kaltwasser

DOI: $10.1046 / \mathrm{j} .1365-2370.2000 .00215 . x$

European Journal of Haematology

Vol 74 Issue 4

Prevalence of the H63D mutation of the HFE in north India: its presence does not cause iron overload in beta thalassemia trait

Gurjeewan Garewal, Reena Das, Jasmina Ahluwalia and R. K. Marwaha

DOI: 10.1111/j.1600-0609.2004.00390.x

Transfusion Clinique et Biologique

Volume 13, Issue 6, December 2006, Pages 353-357

Mutations du gène HFE chez des $\beta$-thalassémiques majeurs tunisiens et surcharge en fer

HFE gene mutations in Tunisian major $\beta$-Thalassemia and iron overload

F. Mellouli, W. El Borgi, H. Kaabi, E. Ben Hassen, R. Sassi, H. Hmida, G. Cherif, M. Maamar, B. Zouari, K. Boukef, M. Bejaoui, S. Hmida

DOI: 10.1016/j.tracli.2006.12.002 
Journal of Gastroenterology and Hepatology

Volume 28, Issue 7, pages 1087-1094, July 2013

Iron storage disease in Asia-Pacific populations: The importance of non-HFE mutations

Cameron J McDonald, Daniel F Wallace, Darrell H G Crawford, V Nathan Subramaniam

DOI: $10.1111 /$ jgh.12222

Cold Spring Harb Perspect Med

2012;2:a011726

Pathophysiology and Clinical Manifestations of the $\beta$-Thalassemias
Arthur W. Nienhuis and David G. Nathan

DOI: 10.1101/cshperspect.a011726

As such the validity of the content of this article cannot be verified. 